\title{
A faunistic and ecological characterization of the water mites (Acari: Hydrachnidia) of the Bukowa River (central-eastern Poland)
}

\section{ROBERT STRYJECKI, ${ }^{1}$ AlEKSANDRA BAŃKOWSKA, ${ }^{2}$ MAGDALENA SZENEJKO ${ }^{3}$}

\footnotetext{
Department of Zoology, Animal Ecology and Wildlife Management, University of Life Science in Lublin, Akademicka 13, 20-950 Lublin, Poland, e-mail: robstry@wp.pl

2 Department of Invertebrate Zoology and Limnology, University of Szczecin, 71-415 Szczecin, Wąska 13, Poland. alekbankow@ gmail.com

${ }^{3}$ Department of Ecology and Environmental Protection, Institute for Research on Biodiversity, Faculty of Biology, University of Szczecin, Poland, e-mail: magdalena.szenejko@usz.edu.pl
}

Keywords lentic zone, lotic zone, longitudinal profile of the river, synecological groups, species diversity

Abstract The water mite communities of the Bukowa River were found to be similar to those of other lowland rivers in Poland. An element specific to the Bukowa River was a much higher abundance of Lebertia inaequalis than in other Polish rivers. Another distinctive element was the very high numbers of Arrenurus crassicaudatus, but this taxon should be considered allochthonous - its presence in the river was due to the periodic inflow of water from fish ponds. The largest synecological group was rheophiles and rheobionts, which together accounted for $80 \%$ of the fauna. The very large quantitative share of rheobionts and rheophiles is indicative of the natural character of the river, and the physicochemical parameters confirm its good water quality. More individuals (1,764) and species (47) were caught in the lentic zone of the river than in the lotic zone (1,027 individuals, 32 species). The species most associated with the lotic zone and fast water flow were Sperchon clupeifer and Hygrobates calliger. Data from the Bukowa River, as well as other rivers of the Janów Forests Landscape Park, indicate that the most characteristic habitat for Lebertia inaequalis is the lentic zone, with abundant water vegetation. The typical habitats of Hygrobates setosus are marginal pools and zones with slower water flow. Mideopsis crassipes and Torrenticola amplexa were associated with the upper course of the river. Sperchon clupeifer was associated with lotic habitats of the middle and lower course of the river, and Hygrobates setosus and Forelia variegator were associated with habitats with slower flow in the middle and lower stretches of the river.

\footnotetext{
Faunistyczna i ekologiczna charakterystyka wodopójek (Acari: Hydrachnidia) rzeki Bukowa (Polska środkowo-wschodnia)

Słowa kluczowe strefa lenityczna, strefa lotyczna, profil podłużny rzeki, grupy synekologiczne, różnorodność gatunkowa
}

Streszczenie Uznano, że zbiorowiska wodopójek z rzeki Bukowej są podobne do innych zbiorowisk z rzek 
nizinnych w Polsce. Elementem charakterystycznym dla rzeki Bukowej była znacznie większa liczebność Lebertia inaequalis niż w innych polskich rzekach. Innym wyróżniającym ją elementem była bardzo wysoka liczba Arrenurus crassicaudatus, ale ten takson powinien być uważany za allochtoniczny - jego obecność w rzece była spowodowana okresowym napływem wody ze stawów rybnych. Największą grupą synekologiczną były reofile i reobionty, które łącznie stanowiły $80 \%$ fauny. Bardzo duży ilościowy udział reobionów i reofili świadczy o naturalnym charakterze rzeki, a parametry fizykochemiczne potwierdzają jej dobrą jakość wody. Więcej osobników (1764) i gatunków (47) zostało złowionych w strefie lenitycznej rzeki niż w strefie lotycznej (1027 osobników, 32 gatunki). Gatunkiem najbardziej związanym ze strefą lotyczną i szybkim przepływem wody były Sperchon clupeifer i Hygrobates calliger. Dane z rzeki Bukowej, a także z innych rzek Parku Krajobrazowego Lasy Janowskie wskazują, że najbardziej charakterystycznym siedliskiem dla Lebertia inaequalis jest strefa lenityczna z obfitą roślinnością wodną. Typowe siedliska Hygrobates setosus to zastoiska i strefy o wolniejszym przepływie wody. Mideopsis crassipes i Torrenticola amplexa były związane z górnym biegiem rzeki. Sperchon clupeifer był związany z siedliskami lotycznymi środkowego i dolnego biegu rzeki, a Hygrobates setosus i Forelia variegator były związane z siedliskami o wolniejszym przepływie w środkowych i dolnych odcinkach rzeki.

\section{Introduction}

The water mite fauna of flowing water bodies in Poland is less well-known than the Hydrachnidia fauna of standing waters. Data on water mites of flowing waters in lowland areas of Poland can be found in works by Pieczyński (1960), Bazan-Strzelecka $(1964,1986)$, Biesiadka (1970, 1972), Biesiadka and Kasprzak (1977), Kowalik (1981), Cichocka (1996a, 1996b, 2006), Stryjecki (2009, 2010), Stryjecki et al. (2012), Zawal and Sadanowicz (2012), Stryjecki and Kowalczyk-Pecka (2013a), Zawal and Kowalik (2013), Bańkowska et al. (2015) and Zawal et al. (2017). Hydrachnidia communities of rivers in the highlands of Poland are described in studies by Kowalik (1981), Kowalik and Biesiadka (1981), Stryjecki and Kowalczyk-Pecka (2013b), Kowalik et al. (2014) and Biesiadka et al. (2015). The rivers of mountainous areas and foothills are by far the least well researched. The most important works on these areas include studies by Kupiszewska (1965), Biesiadka (1974, 1979), Biesiadka and Cichocka (1993). Among the studies cited above, particularly valuable are those which take into account longer stretches of rivers or their entire course (Bazan-Strzelecka, 1964; Biesiadka, 1970, 1979; Kowalik, 1981; Cichocka, 1996a, 2006; Zawal et al., 2017). Due to the lack of studies on the water mite fauna of the rivers of Poland, there is a need for more intensive research on flowing water bodies to provide more complete knowledge of the Hydrachnidia communities of these ecosystems.

Polish rivers are undergoing increasing anthropogenic transformations, most commonly water pollution, but also other forms of human impact, such as regulation of the river bed and modification of the structure of the banks and bottom of watercourses (Biesiadka, 1972; Biesiadka, Kasprzak, 1977; Kowalik, 1981; Kowalik, Biesiadka 1981; Cichocka, 1996a; Zawal, Kowalik, 2013; Zawal et al., 2015). The effect of human impact is increasing impoverishment of fauna. Therefore, there is an urgent need to document the state of Hydrachnidia fauna of rivers, especially natural and unpolluted watercourses (Cichocka, 1996a, 2006).

In addition to species that have established habitat preferences and are characteristic of watercourses (rheobionts and rheophiles), there are taxa that are found in both flowing and standing water bodies. An example of such a species is Hygrobates longipalpis. In the European Hydrachnidia identification key by Gerecke et al. (2016), standing and slow-flowing waters are specified as the habitat of $H$. longipalpis. In the catalogue of Polish fauna (Biesiadka, 2008), the 
species is referred to as a lake species that is also found in flowing waters. This species is classified in different ways in the literature - both as stagnophile (Kowalik, 1981; Zawal, Kowalik, 2013) and as a rheophile (Cichocka, 1996; Zawal, Sadanowicz, 2012). Intensified research on rivers, apart from identification of the fauna of these ecosystems, may contribute to a fuller understanding of the habitat requirements and ecological character of certain species, especially taxa encountered in both flowing and standing water bodies. An additional issue is the provision of new information on taxa that have only recently been recognized as separate species. An example is Hygrobates setosus, which is a sister species of H. nigromaculatus. The river species (H. setosus) was finally separated from the lake species (H. nigromaculatus) relatively recently (Martin et al., 2010). Older publications on flowing waters include $H$. nigromaculatus in the list of species, although it is highly likely that the species in question was $H$. setosus. Documentation of the habitat preferences of Hygrobates setosus is important because it contributes to more complete knowledge of the habitat preferences of this species.

The aim of the study was a detailed faunistic and ecological analysis of the water mite fauna of the natural, unpolluted Bukowa River (central-eastern Poland). We analysed variation in environmental factors, species composition of fauna, dominance structure, species diversity, faunistic similarity, distribution of fauna in the transverse and longitudinal profiles of the river, and synecological structure, as well as the habitat preferences of selected species.

\section{Study area and sites}

The Bukowa River is $54.2 \mathrm{~km}$ long (Michalczyk, Wilgat, 1998). For its entire length it flows through the Biłgoraj Plain mesoregion, which is part of the Sandomierz Basin geographic macroregion (Kondracki, 2014). The Bukowa River is a right-bank tributary of the San River. The river begins in a swamp near the village of Korytków. The headwaters of the river, a stretch of a dozen or so metres flowing south-west, has the appearance of a ditch. The river valley dissects a sandy, mostly forested area with numerous sand dunes. The Bukowa River basin covers an area of $650.8 \mathrm{~km}^{2}$. In the upper and middle course of the river, its basin is highly asymmetrical, with all major tributaries coming from the right side. In its final stretch, the river flows through the valley of the San River, which it falls into at an altitude of $147 \mathrm{~m}$ above sea level. The difference in altitude between the beginning of the river and its mouth is about $75 \mathrm{~m}$, for an average drop of 1.4\%o. The Bukowa discharges on average $4.9 \mathrm{~m}^{3} / \mathrm{s}$ into the San (Michalczyk, Wilgat, 1998). The Bukowa River is the largest river in the Janów Forests Landscape Park. The park is located at an altitude of 150-220 m above sea level, and its relief is not very diverse. The forests are crossed by numerous parallel valleys of small rivers and streams flowing from the edges of upland areas. An important element of the hydrographic network of the park is its numerous swamps and peatlands. Numerous wetlands and fragments of river valleys are occupied by large fish pond complexes situated among forests (Rąkowski et al., 2004).

Five sites were designated on the Bukowa River.

Site 1 - in Korytków Duży (50³6'52.5”N; 22³7'43.5'E)

A site located about $5 \mathrm{~km}$ from the source. The river here had the character of a meadow stream. It was regulated, with a bed about $1 \mathrm{~m}$ wide and $0.2-0.5 \mathrm{~m}$ deep. The bottom was sandy; by the banks and in places with abundant vegetation it was composed of silt or sand and silt. Veronica anagallis-aquatica L., Sparganium erectum L. em. Rchb. s. s. and Elodea canadensis Michx. grew in the lotic zone. Scirpus sylvaticus L., Juncus effusus L., Galium palustre L., Carex 
vesicaria L., C. canescens L. and flooded grasses grew by the banks. In places with a slow current, the surface of the water was covered with Lemna minor L. and L. trisulca L. There were large fluctuations in the water flow at this site, depending on precipitation (Table 1).

Site 2 - in Szewce $\left(50^{\circ} 35^{\prime} 27.1^{\prime \prime} \mathrm{N} ; 22^{\circ} 30^{\prime} 34.7^{\prime \prime} \mathrm{E}\right)$

A site located about $15 \mathrm{~km}$ from the source. The river here had the character of a meadow stream. The river bed was winding, lay deep below the ground surface, and was about $1.5 \mathrm{~m}$ wide, in places (at the meanders) up to $3 \mathrm{~m}$. The depth was varied, from 0.8 to $1.3 \mathrm{~m}$. Lotic zone: bottom covered with a thin layer of sandy sediments with compact clay underneath, nearly devoid of vegetation. Sparse Fontinalis sp. was present on sunken trunks and branches. Lentic zone: sparse, flooded vegetation by the banks, including Galium uliginosum L., G. palustre, Carex nigra Reichard and Iris pseudacorus L.

Site 3 - in Momoty Górne (50³6 $\left.02.5^{\prime \prime} \mathrm{N} ; 22^{\circ} 25^{\prime} 12.7^{\prime \prime} \mathrm{E}\right)$

A site located about $23 \mathrm{~km}$ from the source, within a forest. The width of the riverbed varied from 8 to $10 \mathrm{~m}$. This section of the river was hydro-morphologically varied. Over a dozen or so metres there were riffles, pools, and sandbanks. Water flow was laminar, in some places turbulent. Depth varied from $0.2 \mathrm{~m}$ to $1.5 \mathrm{~m}$, on average $0.5 \mathrm{~m}$. The bottom was sandy over nearly the entire cross-section of the river, but rocky over a stretch that was similar to a mountain river, and composed of sand and silt or silt in the marginal pools. Aquatic vegetation was sparse. In the lotic zone, a few isolated specimens of Sparganium erectum and Fontinalis sp. were present. Veronica anagallis-aquatica, Mentha aquatica L. and flooded Poa palustris L. grew by the banks. Water from fish ponds was periodically discharged into the river.

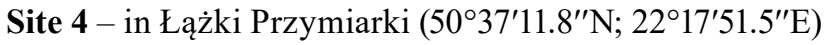

About $33 \mathrm{~km}$ of the course of the river, within a forest. The river meandered slightly. It lay quite deep below the ground surface, and was about $8 \mathrm{~m}$ wide and $1 \mathrm{~m}$ deep. The bottom was sandy over nearly the entire transverse profile of the river, with small amounts of silt in the marginal pools. Numerous embankments and shoals. Water current quite fast (Table 1), uniform water flow. Vegetation sparse. In the lotic zone there were isolated stems of Sparganium erectum. Closer to the banks there was more abundant Elodea canadensis, Batrachium aquatile (L.) Dumort. and Potamogeton pusillus L. Flooded Scirpus sylvaticus, Sium latifolium L., Phalaris arundinacea L. and Poa palustris grew by the banks.

Site 5 - in Szwedy $\left(50^{\circ} 37^{\prime} 12.7^{\prime \prime} \mathrm{N} ; 22^{\circ} 14^{\prime} 12.2^{\prime \prime} \mathrm{E}\right)$

Site located about $40 \mathrm{~km}$ from the sources. Shaded, hydro-morphologically diverse stretch of the river. Width up to $13 \mathrm{~m}$, depth varied, on average $0.6 \mathrm{~m}$. Sandy sediments, not very thick, with clay shale underneath. In the vegetation zone by the banks there were sediments of clay and silt, but the bottom was rocky over a stretch that was similar to a mountain river. The current was quite fast (Table 1), the flow was turbulent in places, uniform over the course of the year. The lotic zone was nearly devoid of vegetation; there were only a few clumps of Potamogeton crispus L. and aquatic mosses forming mats. In the lentic zone, Scirpus sylvaticus and flooded grasses were dominant. 


\section{Methods and material}

\section{Field research}

The field research was conducted mainly from April to November 1996 and from May to October 1997. Samples were taken once a month. At each site samples were taken from two zones of the river: the lentic zone (near the riverbanks) and the lotic zone (in the middle of the river). Sampling was done with a hand net. The net had a round frame with a $0.25 \mathrm{~m}$ diameter and 250 $\mu \mathrm{m}$ mesh size. A single sample was taken over a distance of about $10 \mathrm{~m}$. A total of 160 samples were collected. The material comprised a total of 2,791 individuals. The material collected in the field was transported to the laboratory and segregated in white cuvettes. The following works were used for identification of water mites: Viets (1936), Sokolov (1940), Davids et al. (2007), Di Sabatino et al. (2010), and Gerecke et al. (2016). Species nomenclature and systematics were adopted according to Davids et al. (2007), Di Sabatino et al. (2010) and Gerecke et al. (2016). Allocation of species to synecological groups was based on literature data (Smit, van der Hammen, 2000; Davids et al., 2007; Di Sabatino et al., 2010; Gerecke et al., 2016), taking into account the specificity of Poland (Biesiadka, 2008) and the region under investigation (Kowalik, 1984).

During collection of hydrobiological samples, the basic physical and chemical indicators of the water were measured: temperature $\left({ }^{\circ} \mathrm{C}\right), \mathrm{pH}$, electrolytic conductivity $(\mu \mathrm{S} / \mathrm{cm})$, dissolved oxygen $\left(\mathrm{mg} \mathrm{O}_{2} / \mathrm{l}\right)$, and water saturation with oxygen $(\%)$. The measurements were made using a Slandi kit (TM204 thermometer, $\mathrm{PH} 204$ pH meter and CM204 conductivity meter) and an Elmetron CX401 multifunction meter. The water current was determined by the floating object method, by measuring the object's flow time over a distance of $10 \mathrm{~m}$.

\section{Statistical analyses}

Descriptive statistics (sums, means, range, and standard deviation) were calculated using PAST ver. 3.16/2017 software (Hammer et al., 2001). The same software was used to calculate the Shannon-Wiener index ( $\left.\mathrm{H}^{\prime}\right)$. Analyses of quantitative faunistic similarities based on the Bray-Curtis formula were carried out using BioDiveristy Pro ver. 2 software (McAleece et al., 1997). Similarity dendrograms were generated using BioDiveristy Pro software. Group Average was used to create clusters. Correspondence analysis (CA) was also performed using this software.

The normality of the data distribution was checked by the Shapiro-Wilk test in Statistica 13.1 software. The Mann-Whitney U test (Z) was used to compare two independent samples. The Kruskal-Wallis test $(\mathrm{H})$ or one-way ANOVA (depending on the data distribution) was used to compare multiple independent samples. The Spearman correlation coefficient $\left(\mathrm{R}_{\mathrm{S}}\right)$ was used to determine the relationship between parameters. All tests were carried out in Statistica 13.1 software. The statistical significance level was set at $p<0.05$.

\section{Results}

\section{Physicochemical properties of the water and water current}

The water temperature ranged from $2.6^{\circ} \mathrm{C}$ to $20.1^{\circ} \mathrm{C}$. Both extreme values were found at Site 1 (Table 1), and the greatest temperature fluctuations during the study period were found at this site $( \pm$ SD 4.81$)$. In the longitudinal profile of the river, the average water temperature at the first two sites was higher than at the other three (Table 1), but the differences in water temperature 
between sites were not statistically significant (ANOVA F $(4,68)=0.33332, \mathrm{p}=0.85462$ ). Water $\mathrm{pH}$ values ranged from 6.00 to 8.01 (Table 1). Differences in $\mathrm{pH}$ between the sites were statistically significant (ANOVA $F(4,68)=3.3571, \mathrm{p}=0.01442$ ). Post-hoc tests showed a statistically significant difference (Tukey test, $\mathrm{p}=0.0256$ ) in $\mathrm{pH}$ between Site 2 (lowest mean $\mathrm{pH}$ ) and Site 5 (highest mean $\mathrm{pH}$; Table 1). In the longitudinal profile of the river, the first two sites had lower average water $\mathrm{pH}$ than the other three. Electrolytic conductivity ranged from 123 to $684 \mu \mathrm{S} / \mathrm{cm}$ (Table 1). The lowest mean electrolytic conductivity was found at Site $2(202 \mu \mathrm{S} / \mathrm{cm})$ and the highest at Site $3(273 \mu \mathrm{S} / \mathrm{cm})$. Differences in electrolytic conductivity between the sites were not statistically significant (Kruskal-Wallis test: $\mathrm{H}(4, \mathrm{~N}=73)=5.613654, \mathrm{p}=0.2299)$. The oxygen content in the water ranged from 6.40 to $11.78 \mathrm{mg} \mathrm{O}_{2} / 1$ (Table 1). There was substantial variation in oxygen conditions between the sites, but the differences were not statistically significant (ANOVA, $\mathrm{F}(4,49)=2.2947, \mathrm{p}=0.07248$ ). The best oxygen conditions were found at Site 5 (average $8.69 \mathrm{mg}$ $\mathrm{O}_{2} / 1, \pm \mathrm{SD} 1.92$ ), and the worst at Site 1 (average $6.61 \mathrm{mg} \mathrm{O}_{2} / 1, \pm \mathrm{SD} 1.77$ ). The oxygen saturation of the water ranged from $38.0 \%$ to $115.7 \%$ from 6.40 to $11.78 \mathrm{mg} \mathrm{O}_{2} / 1$ (Table 1).

Table 1. Values of analyzed environmental parameters (range; mean; \pm SD). a, b - the differences in the values between particular sites were statistically significant

\begin{tabular}{|l|c|c|c|c|c|}
\hline \multicolumn{1}{|c|}{ Parameter } & Site 1 & Site 2 & Site 3 & Site 4 & Site 5 \\
\hline \multirow{2}{*}{ Temperature $\left({ }^{\circ} \mathrm{C}\right)$} & $2.6-20.1 ;$ & $4.7-19.7 ;$ & $4.8-16.5 ;$ & $4.1-16.9 ;$ & $3.9-17.0 ;$ \\
& $12.5 ; \pm 4.81$ & $12.7 ; \pm 4.57$ & $11.7 ; \pm 3.72$ & $11.2 ; \pm 4.08$ & $11.4 ; \pm 4.36$ \\
\hline \multirow{2}{*}{$\mathrm{pH}$} & $6.51-7.30 ;$ & $6.00-7.61 ;$ & $6.10-7.72 ;$ & $6.70-7.79 ;$ & $6.45-8.01 ;$ \\
& $6.88 ; \pm 0.21$ & $6.81^{\mathrm{a}} ; \pm 0.49$ & $7.10 ; \pm 0.39$ & $7.16 ; \pm 0.33$ & $7.25^{\mathrm{b}} ; \pm 0.43$ \\
\hline Electrolytic conductivity & $138-468 ;$ & $123-317 ;$ & $132-684 ;$ & $125-274 ;$ & $144-441 ;$ \\
$(\mu \mathrm{S} / \mathrm{cm})$ & $259 ; \pm 98.68$ & $202 ; \pm 63.68$ & $273 ; \pm 145.01$ & $210 ; \pm 43.46$ & $253 ; \pm 82.27$ \\
\hline Dissolved oxygen $(\mathrm{mg}$ & $3.60-9.91 ;$ & $5.60-10.80 ;$ & $5.90-10.66 ;$ & $5.40-11.78 ;$ & $5.60-11.66 ;$ \\
$\left.\mathrm{O}_{2} / \mathrm{l}\right)$ & $6.61 ; \pm 1.77$ & $8.02 ; \pm 1.58$ & $7.82 ; \pm 1.56$ & $8.53 ; \pm 2.09$ & $8.69 ; \pm 1.92$ \\
\hline Water saturation with & $38.0-82.4 ;$ & $55.0-93.4 ;$ & $57.0-87.2 ;$ & $56.0-109.9 ;$ & $56.0-115.7 ;$ \\
oxygen $(\%)$ & $63.9^{\mathrm{a}} ; \pm 13.65$ & $79.2 ; \pm 12.33$ & $75.0 ; \pm 9.75$ & $81.7^{\mathrm{b}} ; \pm 17.13$ & $83.9^{\mathrm{b}} ; \pm 16.2$ \\
\hline \multirow{2}{*}{ Water current $(\mathrm{m} / \mathrm{s})$} & $0.12-0.62 ;$ & $0.14-0.66 ;$ & $0.21-0.50 ;$ & $0.43-1.0 ;$ & $0.50-0.83 ;$ \\
& $0.33^{\mathrm{a}} ; \pm 0.16$ & $0.37^{\mathrm{a}} ; \pm 0.17$ & $0.39^{\mathrm{a}} ; \pm 0.10$ & $0.62^{\mathrm{b}} ; \pm 0.13$ & $0.68^{\mathrm{b}} ; \pm 0.12$ \\
\hline
\end{tabular}

Differences in the values of this parameter between sites were statistically significant (ANOVA F $(4,49)=3.4750, \mathrm{p}=0.01413$ ). Post-hoc tests showed statistically significant differences in oxygen saturation between Sites 1 and 4 (Tukey test, $p=0.040$ ) and between Sites 1 and 5 (Tukey test, $p=0.013$ ). In the longitudinal profile of the river, dissolved oxygen and water saturation with oxygen increased along the course of the river (Table 1). Water current values fluctuated between 0.12 and $1.00 \mathrm{~m} / \mathrm{s}$ (Table 1). The differences observed in this parameter between sites were statistically significant (ANOVA, $F(4,65)=18.361, \mathrm{p}=0.00000$ ). These differences were found for the group of Sites 1, 2 and 3, where the current was slower, and Sites 4 and 5, where it was much faster (Table 1).

\section{Water mite fauna}

General characteristic, the structure of dominance and species diversity

A total of 2,791 individuals belonging to 51 species, 24 genera and 15 families were caught (Table 2). 
Table 2. Qualitative and quantitative composition of water mite fauna found in the Bukowa River. SG synecological group: $\mathrm{Rb}$ - rheobionts, $\mathrm{Rp}$ - rheophiles, $\mathrm{St}$ - stagnobionts and stagnophiles, $\mathrm{S} / \mathrm{R}$ - species occurring both in running and stagnant waters; le - lentic zone of the river, lo - lotic zone of the river, To - total at the site

\begin{tabular}{|c|c|c|c|c|c|c|c|c|c|c|c|c|c|c|c|c|c|c|c|c|}
\hline \multirow{2}{*}{ No. } & \multirow{2}{*}{ Species } & \multirow{2}{*}{ SG } & \multicolumn{3}{|c|}{ Site 1} & \multicolumn{3}{|c|}{ Site 2} & \multicolumn{3}{|c|}{ Site 3} & \multicolumn{3}{|c|}{ Site 4} & \multicolumn{3}{|c|}{ Site 5} & \multicolumn{3}{|c|}{ In the River } \\
\hline & & & le & lo & To & le & lo & To & le & lo & To & le & lo & To & le & lo & To & le & lo & To \\
\hline 1 & 2 & 3 & 4 & 5 & 6 & 7 & 8 & 9 & 10 & 11 & 12 & 13 & 14 & 15 & 16 & 17 & 18 & 19 & 20 & 21 \\
\hline 1. & Limnochares aquatica (L.) & St & & & & 34 & 18 & 52 & & & & & & & & & & 34 & 18 & 52 \\
\hline - & Eylais sp. & - & & 1 & 1 & 1 & 1 & 2 & & & & & & & & & & 1 & 2 & 3 \\
\hline 2. & $\begin{array}{l}\text { Hydrodroma torrenticola } \\
\text { (Walt.) }\end{array}$ & $\mathrm{Rp}$ & & & & 3 & & 3 & & & & 2 & & 2 & & & & 5 & & 5 \\
\hline 3. & Thyopsis cancellata (Protz) & $\mathrm{Cr}$ & & & & & & & & & & 1 & & 1 & 3 & & 3 & 4 & & 4 \\
\hline 4. & Hydryphantes planus Thon & St & & & & & & & & & & & & & 3 & & 3 & 3 & & 3 \\
\hline- & Hydryphantes sp. & - & 1 & & 1 & & & & & & & 2 & & 2 & & & & 3 & & 3 \\
\hline 5. & Nilotonia borneri (Walt.) & $\mathrm{S} / \mathrm{R}$ & & & & & & & & & & & & & 1 & & 1 & 1 & & 1 \\
\hline 6. & Lebertia fimbriata Thor & $\mathrm{Rp}$ & & & & 2 & 11 & 13 & 14 & 7 & 21 & 11 & 10 & 21 & 7 & 12 & 19 & 34 & 40 & 74 \\
\hline 7. & L. oblonga Koen. & $\mathrm{Rp}$ & & & & 19 & 45 & 64 & 38 & 21 & 59 & 14 & 6 & 20 & 12 & 15 & 27 & 83 & 87 & 170 \\
\hline 8. & L. rivulorum Viets & $\mathrm{Rb}$ & & & & 1 & 6 & 7 & 2 & 1 & 3 & 3 & 1 & 4 & 10 & 14 & 24 & 16 & 22 & 38 \\
\hline 9. & L. dubia Thor & $\mathrm{Cr}$ & & 1 & 1 & & & & & & & 1 & & 1 & & & & 1 & 1 & 2 \\
\hline 10. & L. inaequalis (Koch) & $\mathrm{Rp}$ & 25 & 42 & 67 & 62 & 43 & 105 & 80 & 17 & 97 & 49 & 10 & 59 & 29 & 18 & 47 & 245 & 130 & 375 \\
\hline 11. & L. insignis Neum. & $\mathrm{Rp}$ & 2 & & 2 & 10 & 7 & 17 & 3 & 2 & 5 & 11 & 3 & 14 & 5 & 2 & 7 & 31 & 14 & 45 \\
\hline 12. & L. pilosa Maglio & $\mathrm{Rp}$ & & & & 2 & 5 & 7 & & & & & & & & & & 2 & 5 & 7 \\
\hline 13. & L. porosa Thor & $\mathrm{Rp}$ & & & & 5 & 25 & 30 & & 3 & 3 & 2 & & 2 & 1 & 4 & 5 & 8 & 32 & 40 \\
\hline- & Lebertia sp. (deutonymphs) & - & 4 & 1 & 5 & 15 & 7 & 22 & 11 & 3 & 14 & 10 & 1 & 11 & 1 & 3 & 4 & 41 & 15 & 56 \\
\hline 14. & Sperchon clupeifer Piers. & $\mathrm{Rb}$ & & & & 3 & 7 & 10 & 15 & 58 & 73 & 13 & 27 & 40 & 11 & 35 & 46 & 42 & 127 & 169 \\
\hline 15. & S. papillosus Thor & $\mathrm{Rb}$ & & & & & & & & & & & & & & 1 & 1 & & 1 & 1 \\
\hline 16. & S. setiger Thor & $\mathrm{Rb}$ & & & & & 3 & 3 & 4 & 6 & 10 & 38 & 20 & 58 & 5 & 10 & 15 & 47 & 39 & 86 \\
\hline- & Sperchon sp. (deutonymphs) & - & & & & & & & 1 & 3 & 4 & & & & & & & 1 & 3 & 4 \\
\hline 17. & $\begin{array}{l}\text { Sperchonopsis verrucosa } \\
\text { (Protz) }\end{array}$ & $\mathrm{Rb}$ & & & & & & & & & & & 1 & 1 & & 1 & 1 & & 2 & 2 \\
\hline 18. & Teutonia cometes (Koch) & $\mathrm{S} / \mathrm{R}$ & & & & 10 & 1 & 11 & 3 & & 3 & 10 & & 10 & 5 & & 5 & 28 & 1 & 29 \\
\hline 19. & Torrenticola amplexa (Koen.) & $\mathrm{Rb}$ & & & & 90 & 94 & 184 & 9 & 1 & 10 & 3 & 1 & 4 & 3 & & 3 & 105 & 96 & 201 \\
\hline 20. & Albia stationis Thon & $\mathrm{Rp}$ & & & & & & & & & & 3 & & 3 & & & & 3 & & 3 \\
\hline 21. & Axonopsis complanata (Müll.) & St & & & & 1 & & 1 & & & & & & & & & & 1 & & 1 \\
\hline 22. & $\begin{array}{l}\text { Parabrachypoda modesta } \\
\text { (Koen.) }\end{array}$ & $\mathrm{Rp}$ & & & & 8 & 5 & 13 & 3 & & 3 & & & & 2 & & 2 & 13 & 5 & 18 \\
\hline 23. & P. montii (Maglio) & $\mathrm{Rp}$ & & & & 4 & 3 & 7 & & & & & & & & & & 4 & 3 & 7 \\
\hline 24. & Ljania bipapillata Thor & $\mathrm{Rp}$ & & & & & & & & & & 1 & & 1 & & & & 1 & & 1 \\
\hline 25. & Atractides distans (Viets) & $\mathrm{Rb}$ & & & & 1 & & 1 & & & & 3 & & 3 & 1 & 1 & 2 & 5 & 1 & 6 \\
\hline 26. & A. nodipalpis Thor & $\mathrm{Rb}$ & & & & 7 & 16 & 23 & 3 & 5 & 8 & 10 & 10 & 20 & 4 & 8 & 12 & 24 & 36 & 63 \\
\hline 27. & A. spinipes Koch & $\mathrm{Rb}$ & & & & 1 & & 1 & & & & & & & & & & 1 & & 1 \\
\hline
\end{tabular}




\begin{tabular}{|c|c|c|c|c|c|c|c|c|c|c|c|c|c|c|c|c|c|c|c|c|}
\hline 1 & 2 & 3 & 4 & 5 & 6 & 7 & 8 & 9 & 10 & 11 & 12 & 13 & 14 & 15 & 16 & 17 & 18 & 19 & 20 & 21 \\
\hline- & Atractides sp. (deutonymphs) & - & & & & & & & & & & & & & & 1 & 1 & & 1 & 1 \\
\hline 28. & Hygrobates calliger Piers. & $\mathrm{Rb}$ & & & & 46 & 67 & 113 & 20 & 40 & 60 & 22 & 16 & 38 & 8 & 34 & 42 & 96 & 157 & 253 \\
\hline 29. & H. fluviatilis (Ström) & $\mathrm{Rb}$ & 4 & 1 & 5 & 10 & 23 & 33 & & & & 5 & & 5 & 1 & 4 & 5 & 20 & 28 & 48 \\
\hline 30. & H. longipalpis (Herm.) & $\mathrm{S} / \mathrm{R}$ & 54 & 15 & 69 & & 1 & 1 & & & & 1 & & 1 & 4 & 1 & 5 & 59 & 17 & 76 \\
\hline 31. & H. setosus Bess. & $\mathrm{Rp}$ & 2 & 1 & 3 & 2 & 2 & 4 & 33 & & 33 & 35 & 3 & 38 & 27 & 2 & 29 & 99 & 8 & 107 \\
\hline- & Hygrobates sp. (deutonymphs) & - & & & & 4 & 1 & 5 & & 1 & 1 & & & & 1 & 1 & 2 & 5 & 3 & 8 \\
\hline 32. & Limnesia maculata (Müll.) & St & & & & & & & 9 & 7 & 16 & 1 & 1 & 2 & & & & 10 & 8 & 18 \\
\hline 33. & L. undulatoides Davids & St & & & & & & & 5 & & 5 & & & & & & & 5 & & 5 \\
\hline- & Limnesia sp. (deutonymphs) & - & & & & & & & 5 & 1 & 6 & & & & & & & 5 & 1 & 6 \\
\hline 34. & Forelia brevipes (Neum.) & St & & & & & & & 2 & & 2 & & & & & & & 2 & & 2 \\
\hline 35. & F. liliacea liliacea (Müll.) & St & & & & & & & 5 & & 5 & & & & & & & 5 & & 5 \\
\hline 36. & F. variegator (Koch) & $S / R$ & 2 & 1 & 3 & 5 & 7 & 12 & 19 & & 19 & 29 & 5 & 34 & 35 & 4 & 39 & 90 & 17 & 107 \\
\hline 37. & Nautarachna crassa (Koen.) & $\mathrm{Rp}$ & & & & 1 & & 1 & 6 & & 6 & & & & & & & 7 & & 7 \\
\hline 38. & Piona carnea (Koch) & St & & & & & & & & & & 1 & & 1 & & & & 1 & & 1 \\
\hline 39. & P. paucipora (Thor) & St & & & & & & & 9 & & 9 & & & & & & & 9 & & 9 \\
\hline 40. & P. pusilla (Neum.) & St & & & & & & & 7 & & 7 & 1 & & 1 & & & & 8 & & 8 \\
\hline- & Piona sp. (deutonymphs) & - & & & & & & & 162 & 7 & 169 & 2 & & 2 & & 1 & 1 & 164 & 8 & 172 \\
\hline 41. & Neumania limosa $($ Koch) & St & & & & & & & 3 & 1 & 4 & & & & & & & 3 & 1 & 4 \\
\hline 42. & Unionicola crassipes (Müll.) & St & & & & & & & 1 & & 1 & & & & & & & 1 & & 1 \\
\hline 43. & $\begin{array}{l}\text { Arrenurus crassicaudatus } \\
\text { Kram. }\end{array}$ & St & & & & & & & 137 & 10 & 147 & 7 & 1 & 8 & 7 & 1 & 8 & 151 & 12 & 163 \\
\hline 44. & A. cylindratus Piers. & $\mathrm{Cr}$ & & 1 & 1 & & & & & & & & & & & & & & 1 & 1 \\
\hline 45. & A. globator (Müll.) & St & & & & 1 & & 1 & 1 & & 1 & & & & & & & 2 & & 2 \\
\hline 46. & A. mediorotundatus Thor & St & & & & & & & & & & & & & 2 & & 2 & 2 & & 2 \\
\hline 47. & A. tubulator (Müll.) & St & & & & & & & 2 & & 2 & & & & & & & 2 & & 2 \\
\hline 48. & A. sinuator (Müll.) & St & & & & & & & & 1 & 1 & & & & & & & & 1 & 1 \\
\hline- & Arrenurus sp. (deutonymphs) & - & & & & & & & 1 & & 1 & & & & & & & 1 & & 1 \\
\hline 49. & Mideopsis crassipes Soar & $\mathrm{Rp}$ & 51 & 39 & 90 & 64 & 25 & 89 & 10 & 1 & 11 & 10 & & 10 & 10 & 1 & 11 & 145 & 66 & 211 \\
\hline 50. & M. orbicularis (Müll.) & St & & & & & & & 8 & 5 & 13 & & & & 1 & & 1 & 9 & 5 & 14 \\
\hline 51. & M. roztoczensis Bies. et Kow. & $\mathrm{Rp}$ & & & & 27 & 10 & 37 & 8 & & 8 & 25 & & 25 & 12 & & 12 & 72 & 10 & 82 \\
\hline - & Mideopsis sp. (deutonymphs) & - & & & & 1 & & 1 & 2 & & 2 & & & & 1 & & 1 & 4 & & 4 \\
\hline \multicolumn{2}{|c|}{ Total individuals } & & 145 & 103 & 248 & 440 & 433 & 873 & 641 & 201 & 842 & 326 & 116 & 442 & 212 & 174 & 386 & 1,764 & 1,027 & 2,791 \\
\hline \multicolumn{2}{|c|}{ Total species } & & 7 & 8 & 9 & 26 & 22 & 28 & 29 & 17 & 31 & 28 & 15 & 29 & 26 & 19 & 28 & 47 & 32 & 51 \\
\hline
\end{tabular}

The dominant species (dominance $>5 \%$ ) in the material were Lebertia inaequalis $(13.4 \%$ ), Hygrobates calliger (9.1\%), Mideopsis crassipes (7.6\%), Torrenticola amplexa (7.2\%), Lebertia oblonga (6.1\%), Sperchon clupeifer (6.1\%) and Arrenurus crassicaudatus (5.8\%). The number of specimens caught at individual sites ranged from 248 to 873 (Table 2). Differences in the 
number of specimens caught at individual sites were not statistically significant (Kruskal-Wallis test: $\mathrm{H}(4, \mathrm{~N}=150)=3.408295 \mathrm{p}=0.4920)$. The number of species caught at individual sites ranged from 9 to 31 (Table 2). A high correlation was found between the number of specimens caught and the number of species found $\left(\mathrm{R}_{\mathrm{S}}=0.84, \mathrm{p}<0.05\right)$.

More individuals and species were found in the lentic zone of the river (1,764 individuals, 47 species), than in the lotic zone (1,027 individuals, 32 species), but the differences in the number of individuals caught in these two zones were not statistically significant $(Z=0.9645$, $\mathrm{p}=0.3347)$. The dominant species in the lentic zone were Lebertia inaequalis (13.9\%), Arrenurus crassicaudatus (8.6\%), Mideopsis crassipes (8.2\%), Torrenticola amplexa $(6.0 \%)$, Hygrobates setosus (5.6\%), H. calliger (5.4\%) and Forelia variegator (5.1\%). The dominant species in the lotic zone were Hygrobates calliger (15.3\%), Lebertia inaequalis (12.7\%), Sperchon clupeifer (12.4\%), Torrenticola amplexa (9.3\%), Lebertia oblonga (8.5\%) and Mideopsis crassipes (6.4\%).

Greater species diversity was found in the lentic zone than in the lotic zone $\left(\mathrm{H}^{\prime}=2.99\right.$ and $\mathrm{H}^{\prime}=2.72$, respectively). As a rule, species diversity was greater in the lentic zone at individual sites (Figure 1). The exception was Site 2, where slightly greater species diversity was found in the lotic zone $\left(\mathrm{H}^{\prime}=2.52 \mathrm{vs}\right.$. $\mathrm{H}^{\prime}=2.43$ in the lentic zone).

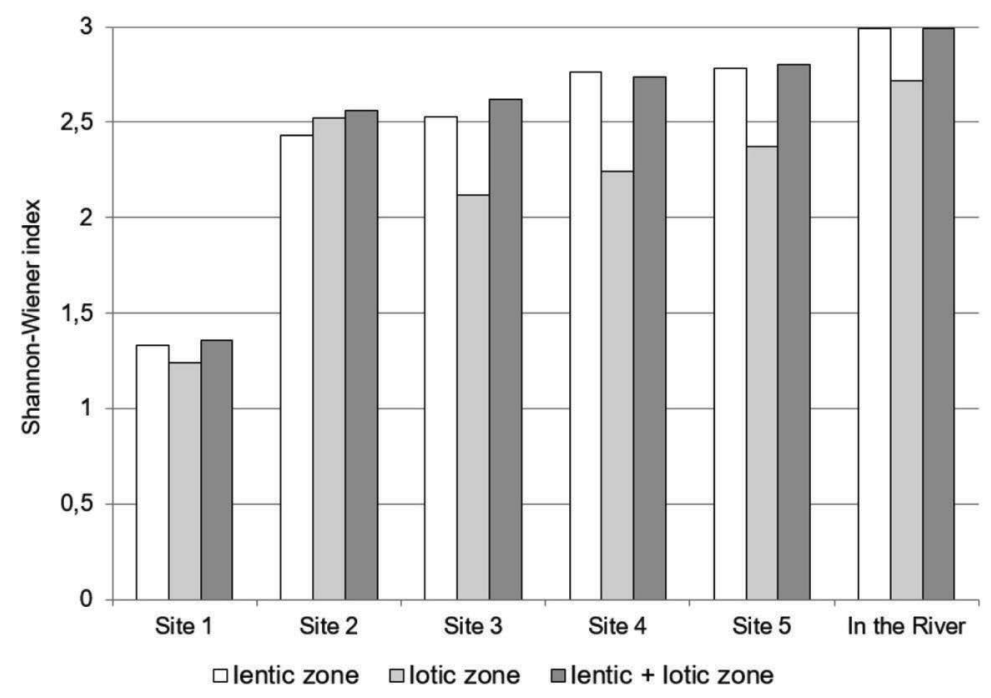

Figure 1. Shannon-Wiener index values at particular sites and lentic and lotic zones in the Bukowa River

\section{Faunistic similarities}

The faunistic similarities between sites ranged from $19.4 \%$ to $78.3 \%$. The similarity dendrogram shows the distinctiveness of the fauna at Site 1, and a group of sites with similar fauna (Sites $3-5$; Figure 2A). The similarities of the fauna of Sites $3-5$ ranged from $54.8 \%$ to $74.3 \%$. In the analysis at the habitat level, the distinctness of the fauna of the lentic and lotic zones at Site 1 from the zones at other sites also stands out (Figure 2B). Within the upper branch of the dendrogram, the highest similarity was found between the lentic and lotic zones at Site 2 (72.1\%). In the group comprising Sites 3-5, the fauna of the lentic zones formed one cluster, and the fauna of the lotic zones formed another cluster (Figure 2B). 

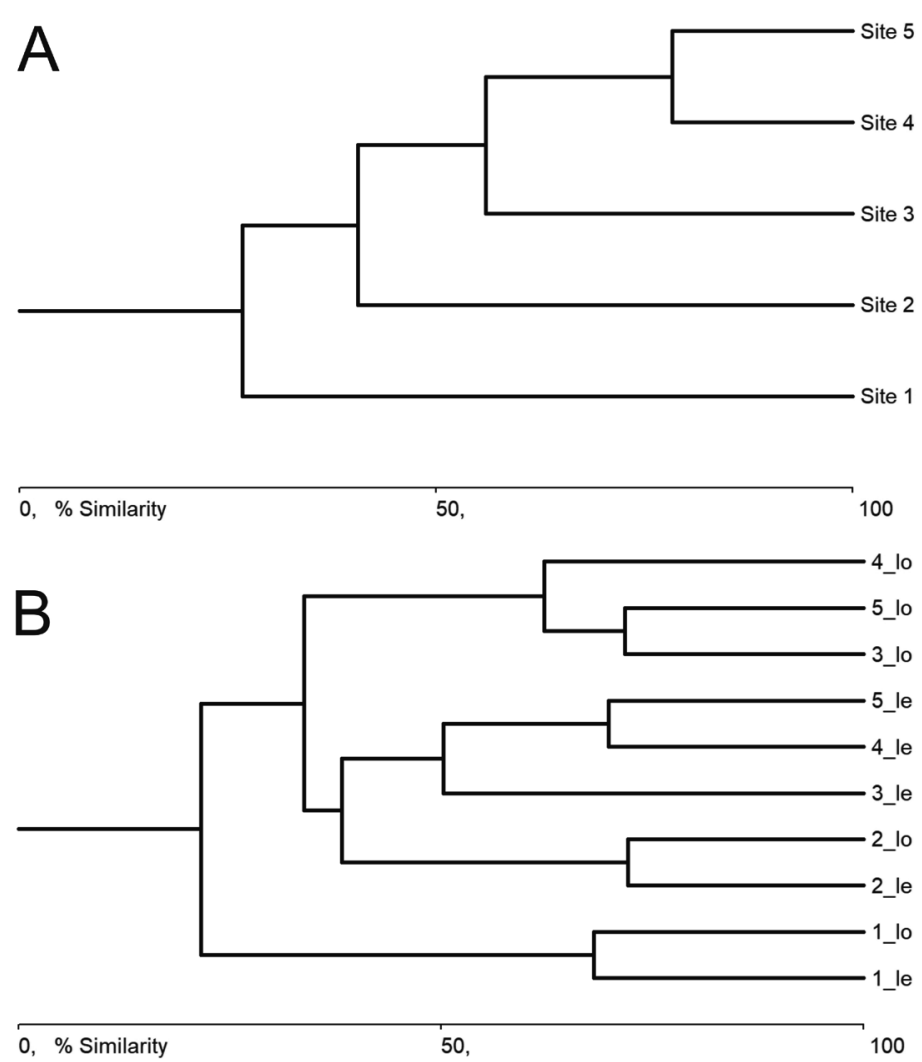

Figure 2. Faunistic similarities between sites (A) and zones (B) in the Bukowa River. 1-5 - sites, le - lentic zone, lo - lotic zone

\section{Synecological structure of fauna}

Rheophiles were the largest synecological group in the Bukowa River (45.6\%, 15 species), followed by rheobionts $(34.4 \%, 11$ species). The group of stagnobionts and stagnophiles comprised many species, but had a much smaller percentage share (11.6\%, 18 species). Species occurring in both running and standing waters (four species) accounted for $11.6 \%$. Three crenophilous species were also distinguished in the structure of the fauna, but very few of these were caught (seven individuals in total; Table 2). Differences were found in the synecological structure of the fauna between the lentic and lotic zones of the river. In the lentic zone, there was a larger proportion of rheophiles, stagnobionts and stagnophiles, and species occurring in both running and standing waters (Figure 3). The last two groups of species, which can be considered less typical of rheocoenoses, together accounted for $27.8 \%$ of the fauna. In the lotic zone, rheobionts constituted $51.5 \%$ of the fauna. Stagnobionts and stagnophiles and the group of species occurring in both running and standing waters together accounted for only $8.1 \%$ in the lotic zone of the river (Figure 3). 


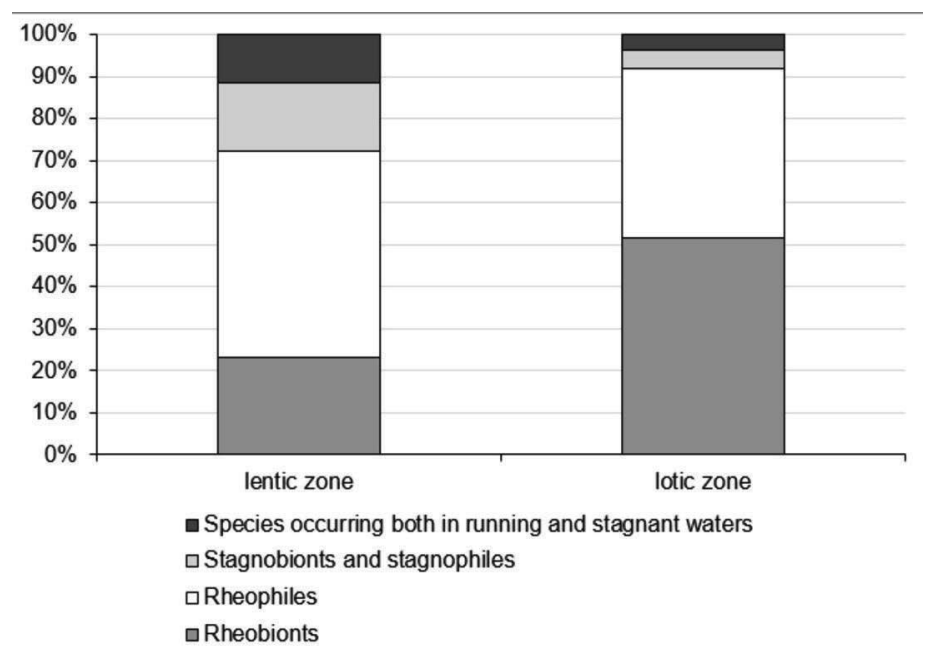

Figure 3. Quantitative synecological structure of water mite fauna in the Bukowa River

\section{Occurrence and distribution of water mites in the transverse profile of the river}

For the nine most abundant species ( $>100$ individuals), distribution among the river zones was analysed. The species most associated with the lotic zone were Sperchon clupeifer (75.1\% of individuals caught in this zone) and Hygrobates calliger (62.1\% of individuals; Figure 4$)$. Both species were found at all sites except Site 1 (Table 2). Lebertia oblonga and Torrenticola amplexa were found in equal numbers in both river zones (Figure 4). Another two species, Lebertia inaequalis and Mideopsis crassipes, were caught more frequently in the lentic zone, but they

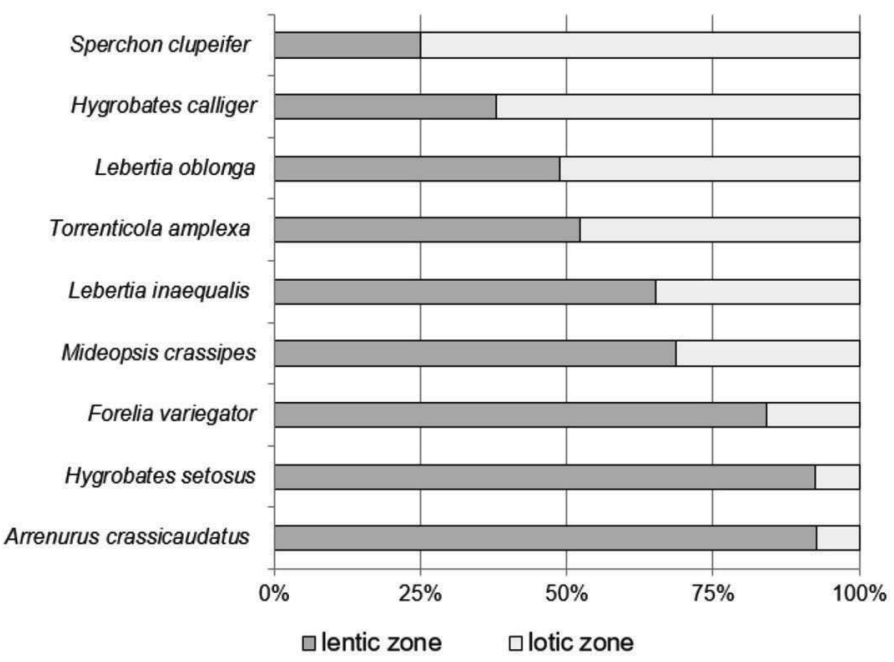

Figure 4. Percentage share of the most numerous species in lentic and lotic zone in the Bukowa River 
were also quite numerous in the lotic zone (Table 2, Figure 4). Two species, Forelia variegator and Hygrobates setosus, can be considered to be associated with the lentic zone; the majority of individuals were caught in this zone (Figure 4). Both species were found in the lentic zone at all sites (Table 2). Arrenurus crassicaudatus, of which $92.6 \%$ of individuals were caught in the lentic zone, was only abundant at one site (Site 3), so it cannot be considered a typical element of the lentic zone of the Bukowa River.

\section{The occurrence of water mites in the longitudinal profile of the river}

The fewest individuals (248) were caught at Site 1 (Figure 5, Table 2). Between Sites 1 and 2 there was a sharp increase in the number of individuals, reaching the highest value of all sites (873 individuals). From Site 2, the number of individuals caught decreased along the course of the river; slightly fewer water mites were caught at Site 3 than at Site 2, and at Sites 4 and 5 a sharp decrease was noted in the number of specimens caught (Figure 5, Table 2). The curve showing the changes in the number of species along the course of the river was similar: after the minimum at Site 1 ( 9 sp.), there was a sharp increase in the number of individuals caught, reaching a maximum at Site 3 (31 sp.), and then the number of species decreased along the course of the river, but not as dramatically as the number of individuals (Figure 5).

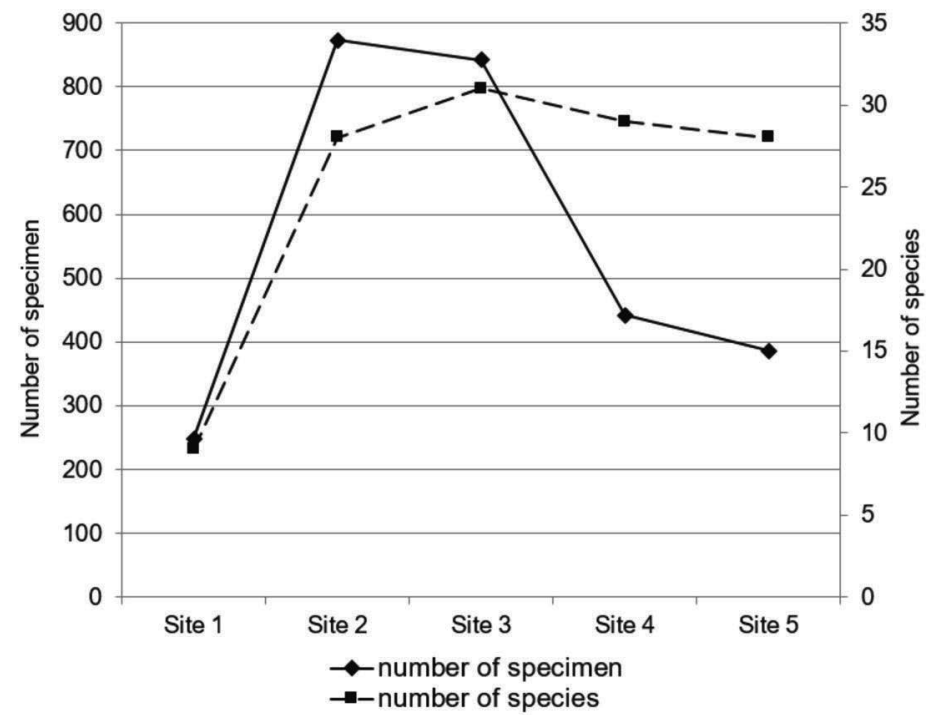

Figure 5. Changes in the number of specimen and species of water mite fauna along the longitudinal profile of the Bukowa River

More detailed analyses of distribution in the longitudinal profile of the river were conducted for the nine most abundant species (abundance $>100$ individuals). For the upper course of the river, the presence of Mideopsis crassipes (Sites 1 and 2) and Torrenticola amplexa (Site 2) was characteristic (Figure 6, cloud 1). Both species were caught in high numbers in both the lotic and lentic zones (Figure 4, Table 2). The position of three species - Lebertia oblonga, L. inaequalis and Hygrobates calliger - near zero on the X axis (site gradient - from Site 1 to Site 5) indicates 
relatively uniform distribution of these species along the course of the river. Arrenurus crassicaudatus was present in high numbers only in the lentic zone of Site 3 (Figure 6, Table 2). Cloud 2 in the CA diagram indicates zonal distribution of Sperchon clupeifer. This species was associated with Sites 3-5, and more specifically, with the lotic zones of these sites (Figure 6). Cloud 3 in the CA diagram groups two species, Hygrobates setosus and Forelia variegator, and two sites (4 and 5), and more specifically, the lentic zones of these sites (Figure 6). Therefore, both species can be regarded as characteristic of the middle course of the river and the beginning of the lower course, and at the same time, as taxa characteristic of the lentic zones of the river (Figure 4).

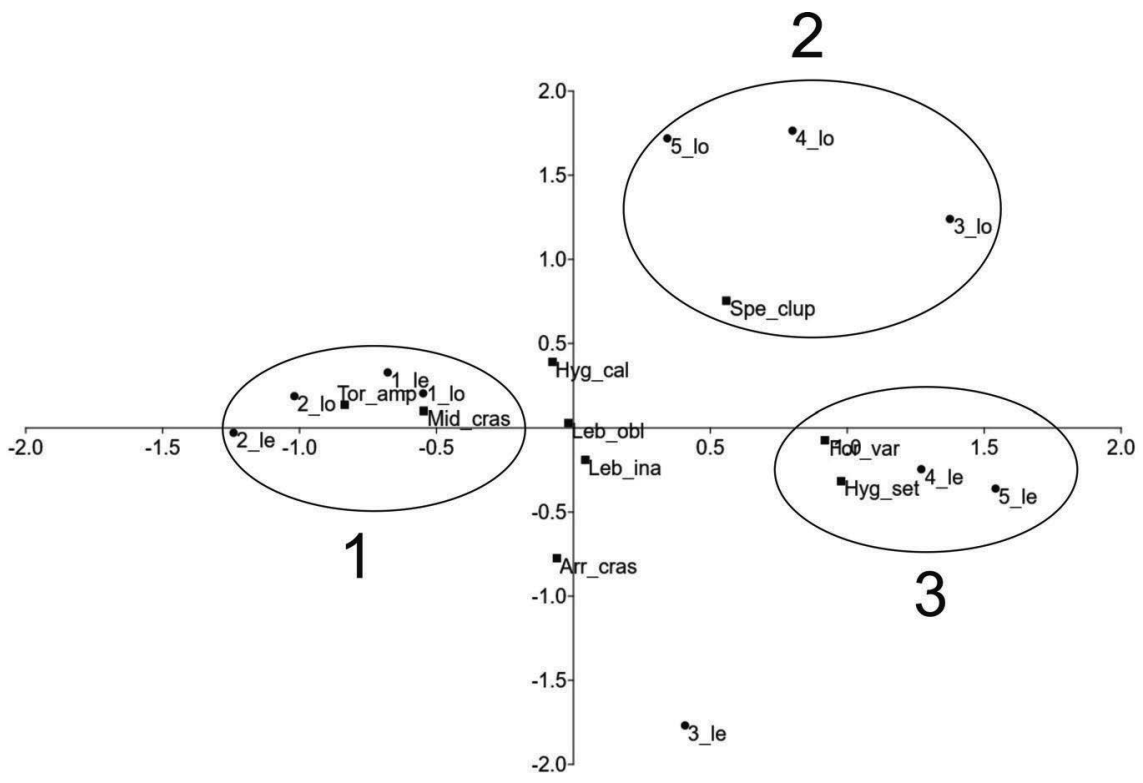

Figure 6. Correspondence analysis (CA) showing occurrence of the most numerous species along the longitudinal profile of the Bukowa River

\section{Discussion}

The water mite communities of the Bukowa River were to a certain degree similar to those of other lowland rivers in Poland, but we can point out certain distinctive elements that distinguish this river from other rivers of Poland. An element specific to the Bukowa River was a much higher abundance of Lebertia inaequalis than in other Polish rivers. This species was even more abundant in other rivers of the Janów Forests Landscape Park (Stryjecki, 2002). L. inaequalis has also been found to be the most abundant species of the genus Lebertia in other rivers of the Biłgoraj Plain (Zawal, Kowalik, 2013). In the neighbouring geographic macroregion of Roztocze, L. inaequalis has been a permanent component of the fauna of rivers, but not so abundant as in the rivers of the Sandomierz Basin (Kowalik, 1981; Stryjecki, Kowaliczyk-Pecka 2013b; Kowalik et al., 2014; Biesiadka et al., 2015). L. inaequalis has been caught in other lowland rivers of Poland (Biesiadka, 1972; Cichocka, 1996a, 2006; Zawal, Sadanowicz, 2012; Zawal et al., 2017), but in none of these has it reached such abundance and dominance as in the Bukowa River and other 
rivers of the Biłgoraj Plain. L. inaequalis has not been found in some other rivers of Poland (Bazan-Strzelecka, 1964; Biesiadka, 1970). This analysis indicates that the abundance of $L$. inaequalis in the rivers of the Sandomierz Basin macroregion and the Biłgoraj Plain mesoregion is a regional characteristic.

The very high abundance of Arrenurus crassicaudatus, which had the status of dominant in the Bukowa River, requires separate explanation. Very high numbers of $A$. crassicaudatus were noted at only one site - just downstream of the mouth of a canal discharging water from fish ponds, in which it was one of the most numerous species (Stryjecki et al., 2015). A. crassicaudatus should be considered an allochthonous element of the Hydrachnidia communities of the Bukowa River, present in the river due to human impact.

A feature common to the Bukowa River and other Polish rivers was the high abundance of the rheobiontic species Hygrobates calliger and Sperchon clupeifer. Hygrobates calliger has attained the status of dominant in certain Polish rivers (Biesiadka, 1970; Cichocka, 1996a), and has been caught in very high numbers in others (Zawal et al., 2017). Sperchon clupeifer has also been found in high numbers in other Polish rivers (Kowalik, 1981; Zawal et al., 2017), sometimes attaining dominant status (Cichocka, 1996a). Other species that were fairly abundant in the Bukowa River and have been caught in other Polish rivers (Biesiadka, 1970, 1972; Kowalik, 1981; Cichocka, 1996a, 2006; Zawal, Sadanowicz, 2012; Zawal et al., 2017) include Lebertia oblonga, Sperchon setiger, Hygrobates fluviatilis, H. setosus and Atractides nodipalpis.

Lowland watercourses have highly diverse water mite fauna, which includes rheobiontic and rheophilic as well as stagnophilic elements, and its character varies with the size of the river and the velocity of the current (Zawal, Sadanowicz, 2012). In the Bukowa River the largest synecological group was rheophiles and rheobionts. These two synecological groups usually dominate in rivers, particularly natural rivers or those little affected by human impact (Biesiadka, 1970, Cichocka, 1996b; Zawal et al., 2017). The dominance of rheophiles and rheobionts has also been noted in other lowland rivers of Poland (Biesiadka, 1970; Cichocka, 1996a, 2006; Zawal, Sadanowicz, 2012; Zawal et al., 2017), as well as upland and lowland rivers of central-eastern Poland (Kowalik, 1981; Stryjecki, Kowaliczyk-Pecka 2013b; Zawal, Kowalik, 2013; Kowalik et al., 2014; Biesiadka et al., 2015). The very large quantitative share of rheophiles and rheobionts in the Bukowa River is indicative of the natural character of this river. According to many authors, human impact and transformation of aquatic ecosystems cause a change in water mite fauna: rheophilous species, with narrow tolerance for environmental factors (e.g. water current and temperature or nutrient level), are gradually replaced by species with a broader ecological valence, which are often also present in standing water bodies (van der Hammen, Smit, 1996). The values of the physicochemical parameters confirmed the good quality of the water of the Bukowa River.

Fewer species and individuals were caught in the lotic zone of the Bukowa River. Impoverishment of fauna was noted in particular on the sandy bottom with sparse aquatic vegetation. Impoverishment of fauna in such habitats has also been reported by other authors (Kowalik, 1981; Cichocka, 1996a). Fewer individuals and species were caught in the lotic zone of the Bukowa River because this zone was uniform in terms of habitat (sandy bottom and lack of plants). In the lowland Pasłęka River, with well-developed current habitats, over twice as many individuals were caught in the lotic zone of the river than in the marginal pools (Cichocka, 1996a). In the Bukowa River many more individuals and species were caught in the marginal pools and in the central part of the river, in places with abundant aquatic vegetation. The results confirm the relationship between abundance of water mites and the degree of abundance of vegetation in water courses (Kowalik, 1981; Cichocka, 1996a, 2006; Zawal, Sadanowicz, 2012; Zawal et al., 2017). 
The species most associated with the lotic zone and fast water flow in the Bukowa River were Sperchon clupeifer and Hygrobates calliger. The results confirm literature data on the preferences of these species for habitats associated with fast water flow (Biesiadka, 1970; Kowalik, 1981; Cichocka, 1996a; Gerecke et al., 2016; Zawal et al., 2017). At the first two sites in the river, the fauna was similar in the lotic and lentic zones. The substantial similarity of the fauna of these two zones was due to the narrowness of the river, which was conducive to intensive migration of species between zones. In the case of small rivers, the presence of species preferring current habitats is usually noted over the entire cross-section of the river (Zawal, Sadanowicz, 2012).

The most abundant species in the Bukowa River, Lebertia inaequalis, was caught in higher numbers in the lentic zone (65.3\% individuals). According to Kowalik (1981), L. inaequalis shows a considerable predisposition for environments with a moderate current and submerged vegetation. In the Pasłęka River, it has been found to be associated with lentic zones without vegetation (Cichocka, 1996a). In the Krutynia River, L. inaequalis was most abundant in the lotic zone (Cichocka, 2006). According to Smit and van der Hammen (2000), L. inaequalis is found in both running and standing waters. In the Netherlands it has been found in lowland streams (natural and channelized), man-made spring brooks, large lakes, and large canals. In standing water bodies it occupies zones with waves. In Poland it is a typical species of flowing water bodies (Biesiadka, 2008). Data from the Bukowa River, as well as other rivers of the Janów Forests Landscape Park (Stryjecki, 2002), indicate that the most characteristic habitat for this species is the lentic zone of rivers, with abundant aquatic vegetation.

It is worth noting the habitat preferences of Hygrobates setosus. H. setosus is a sister species of $H$. nigromaculatus. The river species (H. setosus) was finally separated from the lake species (H. nigromaculatus) relatively recently (Martin et al., 2010). In earlier studies on flowing water bodies, H. setosus was identified as H. nigromaculatus (Kowalik, 1981). In many other publications the species identified as H. nigromaculatus was probably H. setosus. This is indicated by its abundance in the flowing water bodies discussed by the authors and its classification in these studies as a rheophilous species (Biesiadka, 1979; Cichocka, 1996a, Kowalik et al., 2014), whereas $H$. nigromaculatus is a typical lake species (Martin et al., 2010). In the Bukowa River $H$. setosus showed a very clear preference for the lentic zone of the river $(92.5 \%$ of individuals were caught here). In other rivers of Poland, $H$. setosus has also been caught mainly in marginal pools and habitats with a slow current (Kowalik, 1981; Zawal, Sadanowicz, 2012; Zawal et al., 2017). Documentation of the habitat preferences of Hygrobates setosus is important because it contributes to more complete knowledge of the habitat preferences of this species. The results from the Bukowa River confirm literature data indicating that it is a species typical of flowing water bodies, inhabiting marginal pools and zones with slower water flow.

Forelia variegator was also associated with the lentic zone of the Bukowa River. This is a species found in both flowing and standing water bodies (Biesiadka 2008; Gerecke et al., 2016), so its preference for the lentic zone of rivers is natural. The results obtained confirm the preference of this species for places with a slower water flow in running water bodies (Kowalik, 1981; Cichocka, 1996a, 2006; Zawal et al., 2017).

Site 1 in the river was markedly different from the other sites - the fewest species and individuals were caught here. Over this stretch, the river had the form of a straight ditch. A similar phenomenon of quantitative impoverishment in the upper, unregulated stretch of a river has been found in the Pasłęka River (Cichocka, 1996a). The results confirm literature data indicating that regulation of a river channel causes impoverishment of water mite fauna, mainly the disappearance of rheobionts and rheophiles (Biesiadka, 1972; Martin, 1996; van der Hammen, Smit, 
1996). From Site 2 the number of individuals caught began to decline. This was due to habitat conditions: at Sites 3-5 the bottom was sandy with very sparse vegetation over nearly the entire cross-section of the river. In such habitats water mite fauna is usually less abundant than in places with more aquatic vegetation and a larger share of organic sediments (Kowalik, 1981; Cichocka, 1996a; Zawal, Sadanowicz, 2012). The fairly large number of individuals and maximum number of species at Site 3 were due to the periodic influx of pond water. Allochthonous stagnobiontic species which do not naturally occur in the river entered it together with this water. The influx of these species increased the species richness at the site and the total species richness in the Bukowa River, but disturbed the natural character of the Hydrachnidia communities of the river. Human impact consisting in the introduction of species alien to river fauna should be considered a negative phenomenon.

Zonal occurrence of certain species was noted along the course of the Bukowa River. Mideopsis crassipes and Torrenticola amplexa were associated with the upper course. This type of distribution of these species should be considered an individual characteristic of this river, as both of these species have been caught mainly in the middle course of the Pasłęka River (Cichocka, 1996a), and in the middle and lower course of the Krąpiel River (Zawal et al., 2017). Sperchon clupeifer was associated with the middle and lower course of the river, and more precisely, with the lotic zones of these stretches of the river. At Sites 3-5, a lower average water temperature was recorded than in the upper course of the river, as well as higher oxygen content and oxygen saturation. Furthermore, the water current in the middle and lower course of the river was much faster than in the upper course. For Sperchon clupeifer, as a hemistenothermal rheobiont (Kowalik, 1981), these environmental factors had a fundamental influence on its distribution in the longitudinal profile of the river. In the lowland Krąpiel River, this species was also caught in the largest numbers in the lower course of the river (Zawal et al., 2017). Hygrobates setosus and Forelia variegator were associated with the middle and final stretch of the river (Sites 3-5), and more specifically, with the lentic zones of these stretches. Both species are characteristic of lentic environments by the shore (Kowalik, 1981; Zawal, Sadanowicz, 2012; Zawal et al., 2017), which are poorly developed in the upper course of watercourses.

\section{References}

Bańkowska, A., Kłosowska, M., Stryjecki, R., Zawal, A. (2015). New and rare water mite (Hydrachnidia) species in Polish fauna found in the Krąpiel River and valley water bodies in Ińskie Lake District. Acta Biologica, 22, 15-37.

Bazan-Strzelecka, H. (1964). Water mites (Acari, Hydrachnellae) of certain Warta River environments. Ekologia Polska, 12 (seria A), 337-354.

Bazan-Strzelecka, H. (1986). Wodopójki (Acari, Hydrachnellae) rzeki Grabi. Acta Universitatis Lodziensis Folia Zoologica, 4, 59-69.

Biesiadka, E. (1970). Wodopójki (Hydracarina) dolnego biegu rzeki Wełny. Fragmenta Faunistica, 5, 4355.

Biesiadka, E. (1972). Wodopójki (Hydracarina) Wielkopolskiego Parku Narodowego. Prace Monograficzne Przyrody Wielkopolskiego Parku Narodowego, 5, 1-102.

Biesiadka, E. (1974). Hydracarina of the river Raba and some of its tributaries. Acta Hydrobiologica, 16, 31-50.

Biesiadka, E. (1979). Wodopójki (Hydracarina) Pienin. Fragmenta Faunistica, 24, 97-173. 
Biesiadka, E. (2008). Wodopójki (Hydrachnidia). In: W. Bogdanowicz, E. Chudzicka, J. Pilipiuk, E. Skibińska (eds.), Fauna Polski - charakterystyka i wykaz gatunków (pp. 149-219). Warszawa: Muzeum i Instytut Zoologii PAN, 3.

Biesiadka, E., Cichocka, M. (1993). Środowiskowe rozmieszczenie wodopójek (Hydracarina) w Karkonoszach. In: J. Tomaszewski, J. Sarosiek, S. Szymański (eds.), Geoekologiczne problemy Karkonoszy (pp. 263-273). Wrocław: Wydawnictwo Uniwersytetu Wrocławskiego, 2.

Biesiadka, W., Kasprzak, K. (1977). An investigation on the macrofauna of the River Warta within the city of Poznań. Acta Hydrobiol., 2 (19), 109-122.

Biesiadka, W., Kowalik, W., Ścibior, R. (2015). Water mites (Acari, Hydrachnidia) in three forest and landscape reserves in Roztocze. Annales UMCS, C (70), 29-41.

Cichocka, M. (1996a). Wodopójki (Hydracarina) rzeki Pasłęki. Fragmenta Faunistica, 39, 179-205.

Cichocka, M. (1996b). Wodopójki (Hydracarina) Bagien Biebrzańskich. Fragmenta Faunistica, 39, 207221.

Cichocka, M. (2006). Water mites (Hydrachnidia, Acari) in the running waters of the Masurian Landscape Park. Supplementa ad Acta Hydrobiologica, 8, 33-53.

Davids, C., Di Sabatino, A., Gerecke, R., Gledhill, T., Smit, H., van der Hammen, H. (2007). Acari: Hydrachnidia I. Freshwater Fauna of Central Europe, 7 (2-1), 241-388.

Di Sabatino, A., Gerecke, R., Gledhill, T., Smit, H. (2010). Chelicerata: Acari II. Freshwater Fauna of Central Europe, 7 (2-2).

Gerecke, R., Gledhill, T., Pešić, V., Smit, H. (2016). Chelicerata: Acari III. Freshwater Fauna of Central Europe, 7 (2-3).

Hammer, Ø., Harper, D.A.T., Ryan, P.D. (2001). PAST: Paleontological statistics software package for education and data analysis. Palaeontologia Electronica, 4 (1), 9. Retrived from: http://palaeo-electronica.org/2001_1/past/issue1_01.htm.

Kondracki, J. (2014). Geografia regionalna Polski. Warszawa: Wydawnictwo Naukowe PWN.

Kowalik, W. (1981). Wodopójki (Hydracarina) rzek dorzecza Wieprza. Annales UMCS, C (35), 327-351.

Kowalik, W. (1984). Studia faunistyczno-ekologiczne nad wodopójkami (Hydracarina) południowowschodniej Polski. Rozprawy Naukowe AR w Lublinie, 83, 1-67.

Kowalik, W., Biesiadka, E. (1981). Occurrence of water mites in the River Wieprz polluted with domesticindustry sewage. Acta Hydrobiologica, 23, 331-348.

Kowalik, W., Zawal, A., Buczyńska, E. (2014). Water mites (Acari, Hydrachnidia) of the River Szum and Stream Krupiec in the Roztocze region. Acta Biologica, 21, 75-89.

Kupiszewska, J. (1965). Water-mites (Hydrachnellae) in the River Dunajec. Benthic Fauna of the Dunajec River. Kom. Zagosp. Ziem Górskich PAN, 11, 177-181.

Martin, P. (1996). Faunistisch-ökologische Benthosstudien an den Wassermilben (Hydrachnidia, Acari) zweier Bäche des Norddeutschen Tieflandes (Ostholsteinisches Hügelland, Schleswig-Holstein). Faunistisch-Ökologische Mitteilungen, 7,153-167.

Martin, P., Dabert, M., Dabert, J. (2010). Molecular evidence for species separation in the water mite $H y$ grobates nigromaculatus Lebert, 1879 (Acari, Hydrachnidia): evolutionary consequences of the loss of larval parasitism. Aquatic Science, 72, 347-360.

McAleece, N., Gage, J.D.G., Lambshead, P.J.D., Paterson, G.L.J. (1997). BioDiversity Professional statistics analysis software. London: Jointly developed by the Scottish Association for Marine Science and the Natural History Museum London.

Michalczyk, Z., Wilgat, T. (1998). Stosunki wodne Lubelszczyzny. Lublin: Wydawnictwo UMCS. 
Pieczyński, E. (1960). Kształtowanie się zgrupowań wodopójek (Hydracarina) w różnych środowiskach jeziora Wilkus. Ekologia Polska, 8 (Seria A), 169-198.

Rąkowski, G., Smogorzewska, M., Janczewska, A., Wójcik, J., Walczak, M., Pisarski, Z. (2004). Park Krajobrazowy Lasy Janowskie. In: G. Rąkowski (ed.), Parki krajobrazowe w Polsce (pp. 605-610). Warszawa: Instytut Ochrony Środowiska.

Smit, H., van der Hammen, H. (2000). Atlas of the Dutch water mites (Acari: Hydrachnidia) (in Dutch). Nederlandse Faunistische Mededelingen, 13, 1-266.

Sokolov, I.I. (1940). Paukoobraznyje, Vodjanye klešši. Fauna SSSR. Moskva-Leningrad.

Stryjecki, R. (2002). The impact of human activity on the water mite fauna (Acari, Hydrachnidia) of the „Lasy Janowskie” Landscape Park (South-Eastern Poland). In: F. Bernini, R. Nannelli, G. Nuzzaci, E. de Lillo (eds), Acarid phylogeny and evolution. Adaptations in mites and ticks (pp. 113-119). Dordrecht: Kluwer.

Stryjecki, R. (2009). Water mites (Acari, Hydrachnidia) of the Bug River Valley between Włodawa and Kodeń. Teka Komisji Ochrony i Ksztattowania Środowiska Przyrodniczego O.L. PAN, 6, 335-344.

Stryjecki, R. (2010). Water mites (Acari: Hydrachnidia) of the northern part of Nadwieprzański Landscape Park. Teka Komisji Ochrony i Ksztattowania Środowiska Przyrodniczego O.L. PAN, 7, 388-399.

Stryjecki, R., Pawlęga, K., Ścibior, R. (2012). Habitat distribution of water mites (Acari: Hydrachnidia) in Kozłowiecki Landscape Park. Teka Komisji Ochrony i Kształtowania Środowiska Przyrodniczego O.L. PAN, 9, 224-233.

Stryjecki, R., Kowalczyk-Pecka, D. (2013a). A faunistic and ecological characterization of the water mites (Acari: Hydrachnidia) of the highly anthropologically transformed Mietiulka river in Polesie National Park. Environmental Protection and Natural Resources, 24 (1), 11-15.

Stryjecki, R., Kowalczyk-Pecka, D. (2013b). A synecological characterization of the water mite communities (Acari: Hydrachnidia) of the Tanew River in the Nad Tanwią reserve. Teka Komisji Ochrony i Ksztaltowania Środowiska Przyrodniczego O.L. PAN, 10, 407-416.

van der Hammen, H., Smit, H. (1996). The water mites (Acari: Hydrachnidia) of streams in the Netherlands: distribution and ecological aspects on a regional scale. Netherlands Journal of Aquatic Ecology, 30 (203), 175-185.

Viets, K. (1936). Spinnentiere oder Arachnoidea. VII: Wassermilben oder Hydracarina. Tierwelt Deutschland, 31-32, 1-574.

Zawal, A., Kowalik, W. (2013). Water mites of the Biała Łada and Czarna Łada rivers in the Lublin region. Annales UMCS, C (93), 117-125.

Zawal, A., Sadanowicz, P. (2012). Fauna wodopójek (Hydrachnidia) rezerwatu przyrody „Źródlisko Skrzypowe". Parki Narodowe i Rezerwaty Przyrody, 31 (4), 3-10.

Zawal, A., Stępień, E., Szlauer-Łukaszewska, A., Michoński, G., Kłosowska, M., Bańkowska, A., Myśliwy, M., Stryjecki, R., Buczyńska, E., Buczyński, P. (2015). The influence of dredging of a lowland river (the Krąpiel in NW Poland) on water mite fauna (Acari: Hydrachnidia). Fundamental and Applied Limnology, Volume 186 Nr. 3: 217 - 232.

Zawal, A., Stryjecki, R., Stępień, E., Buczyńska, E., Buczyński, P., Czachorowski, S., Pakulnicka, J., Śmietana, P. (2017). The influence of environmental factors on water mite assemblages (Acari, Hydrachnidia) in a small lowland river - an analysis at different levels of organization of the environment. Limnology, 18, 333-343.

Cite as: Stryjecki, R., Bańkowska, A., Szenejko, M. (2018). A faunistic and ecological characterization of the water mites (Acari: Hydrachnidia) of the Bukowa River (central-eastern Poland). Acta Biologica, 25, 77-94. DOI: 10.18276/ab.2018.25-07. 